\title{
Skeletal variability of the coral Favia gravida (Verrill, 1868) from Brazil
}

\author{
Fernanda Duarte Amaral ${ }^{1,2}$ \& Carla Alecrim Colaço Ramos ${ }^{1}$
}

Biota Neotropica v7 (n3) - http://www.biotaneotropica.org.br/v7n3/pt/abstract?article+bn04307032007

Data Received 29/03/07

Revised 24/10/07

Accepted 22/11/07

${ }^{1}$ Área de Zoologia, Departamento de Biologia, Universidade Federal Rural de Pernambuco - UFRPE, Rua Dom Manoel de Medeiros, s/n, Dois Irmãos CEP 52171-900, Recife, PE, Brazil

${ }^{2}$ Corresponding author: Fernanda Duarte Amaral, e-mail: fdamaral@db.ufrpe.br, http://www.ufrpe.br

\begin{abstract}
Amaral, F.D. \& Ramos, C.A.C. Skeletal variability of the coral Favia gravida (Verrill, 1868) from Brazil. Biota Neotrop. Sep/Dez 2007 vol. 7, no. 3 http://www.biotaneotropica.org.br/v7n3/pt/abstract?article+bn04307032007. ISSN 1676-0603.

The skeletal variability of the coral Favia gravida, a species endemic to Brazil, was quantitatively described including populations from three locations: Tamandaré (state of Pernambuco), Abrolhos (state of Bahia), and Santa Cruz (state of Espírito Santo). Ten colonies were collected from each population and fourteen morphological characters were measured from ten corallites per colony. The results of univariate (among 14 skeletal characters, 7 showed $\mathrm{p}<0.05$ ) analysis provide evidence to suggest that $F$. gravida has considerable morphological plasticity, which may explain its ability to adapt to different ecological conditions. The species also displays polymorphism within and between colonies of each population. Intercolony variation within populations was relevant for most of the variables measured. Canonical discriminant analysis $(r=0.8648)$ showed that the population farthest offshore (Abrolhos) was distinct from the other two (Tamandaré and Santa Cruz), which have been affected by terrigenous sediments carried from the coast. Specimens from Santa Cruz displayed the highest degree of meandrinization.

Keywords: morphological variation, skeletal characters, Favia.
\end{abstract}

\section{Resumo}

Amaral, F.D. \& Ramos, C.A.C. Variabilidade esquelética do coral Favia gravida (Verrill, 1868) do Brasil. Biota Neotrop. Sep/Dez 2007 vol. 7, no. 3 http://www.biotaneotropica.org.br/v7n3/pt/abstract?article+bn04307032007. ISSN 1676-0603.

A variação do esqueleto do coral Favia gravida, uma espécie endêmica do Brasil, foi descrita quantativamente a partir de populações de três localidades, incluindo Tamandaré (Estado de Pernambuco), Abrolhos (Estado da Bahia) e Santa Cruz (Estado do Espírito Santo). Dez colônias foram coletadas de cada população e quatorze caracteres morfológicos foram medidos de dez coralitos por colônia. Os resultados da análise univariada (dentre os 14 caracteres esqueléticos, sete apresentaram $\mathrm{p}<0,05$ ) fornecem evidências que sugerem que $F$. gravida tem uma plasticidade morfológica considerável, o que pode explicar sua habilidade para se adaptar às condições ecológicas diferentes. A espécie demonstra, também, polimorfismo dentro e entre as colônias de cada população. A variação intercolonial dentro de populações foi, também, marcante para a maioria das variáveis medidas. A análise discriminante canônica $(r=0,8648)$ mostrou que a população mais distante da costa (Abrolhos) foi distinta das outras duas (Tamandaré e Santa Cruz), as quais estão sendo afetadas por sedimentos terrígenos provenientes da costa. Os espécimes de Santa Cruz demonstraram o mais alto grau de meandrinização.

Palavras-chave: variação morfológica, caracteres esqueléticos, Favia. 


\section{Introduction}

Scleractinian genera and species traditionally are distinguished on the basis of skeletal characters such as colony growth form, corallite size, and number, arrangement and structural details of septa and costae (Vaughan \& Wells 1943). Since the late $19^{\text {th }}$ century, coral workers have recognized that considerable amounts of morphological variation may occur within coral species, even among different parts of the same colony.

Studies of intraspecific morphological variation have focused upon: colony growth forms (Barnes 1973, Graus \& Macintyre 1982, Fricke \& Schuhmacher 1983), skeletal density bands (Dustan 1975, Hughes 1987), meander complexity (Johnson 1988), corallite architecture, including corallites per area (Wijsman-Best 1974, Brakel 1977, Foster 1978, Veron 1981, Foster 1983, Willis 1985, Budd 1988, Beltrán-Torres \& Carricart-Ganivet 1993, Amaral 1994), and polyp expansion, density of zooxanthellae and other soft tissue characters (Lasker 1979, 1981, Lang 1984, Battey \& Porter 1988). Variation has been observed on a variety of spatial scales; within a single reef environment, among different reef environments on a single reef, and among reefs at different geographic locations. This is caused by complex, interrelated environmental and genetic factors that cannot be disentangled on the basis of morphologic criteria alone.

In previous work, Laborel (1970) observed variation in the morphology of Brazilian Scleractinia at the species level, but the differences were not tested statistically. Mayal \& Amaral (1990) described the ecomorphs of some Brazilian corals, Amaral $(1991,1994)$ and Amaral et al. (2006) statistically analyzed the skeletal variations of some Brazilian Faviidae and other coral families. Antônio-de-Souza \& Amaral (2001) and Santos et al. (2004a,b) studied the skeletal variability of Brazilian Mussidae and Siderastreidae.

Recent research has established relationships between coral skeletal characters, temperature data and climatic changes (Morri et al. 2001), biogeography and speciation (Carlon \& Budd 2002), and biological and environmental controls (Cruz-Piñón et al. 2003, Todd et al. 2004b). On the other hand, recent molecular analysis have challenged many traditional notions concerning the systematics and evolution of scleractinian corals (Chen et al. 2002).

The quantification of coral morphology using tissue-free skeletons often requires colonies, or colony sections, to be removed from the reef. This undesirable destruction can be reduced by using a withtissue technique based on photographic images of living corals (Todd et al. 2004a). Todd et al. (2001) used a photographic technique to examine morphological differences in the living polyps of Favia speciosa sampled from three sites around Singapore.

Descriptions of the patterns of morphological variation are necessary for the elaboration of stable and more precise classification systems, as well as for advances in our understanding of the ecology and evolution for this group (Knowlton et al. 1992, Amaral 1994, Palumbi 1994, Carlon \& Budd 2002, Chen et al. 2002, Stanley Jr. 2003, Merks et al. 2004, Santos et al. 2004a,b, Kruszynski et al. 2006).

The aims of the present study was to (i) quantify and statistically analyze the inter-population variation in skeletons of Favia gravida, and (ii) expand current knowledge of the intraspecific variability of the Faviidae from Brazil. Explanations for the morphological differences displayed by three populations collected at the same depth from geographically separate locations are discussed.

\section{Material and Methods}

\section{Collecting localities}

Tamandaré Beach (Figure 1), between $08^{\circ} 41^{\prime}-08^{\circ} 47^{\prime} \mathrm{S}$ and $035^{\circ} 05^{\prime}-036^{\circ} 06^{\prime} \mathrm{W}$, is situated about $110 \mathrm{~km}$ south of Recife

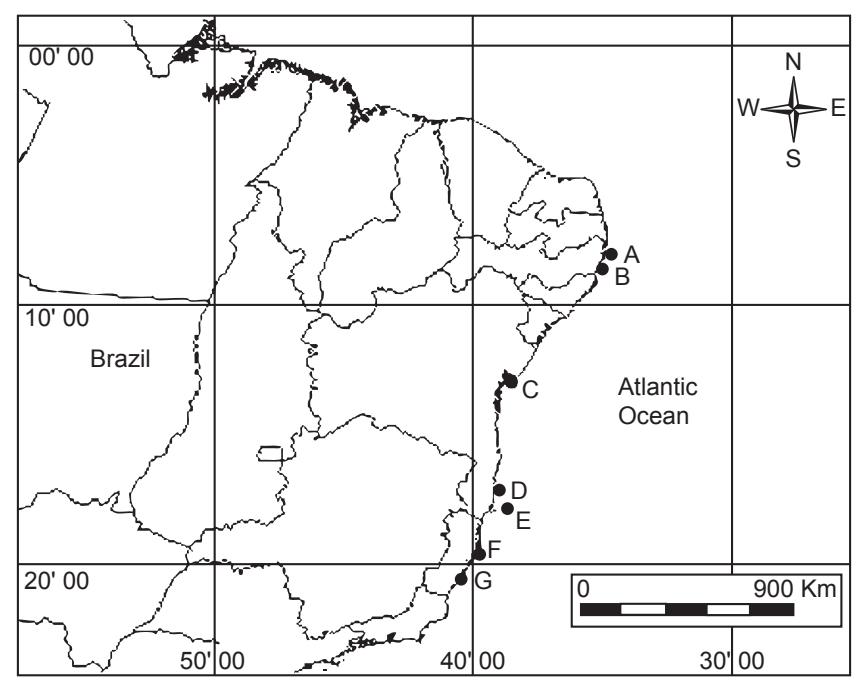

Figure 1. Map of the collecting localities and closest city. $\mathrm{A}=$ Recife city, $\mathrm{B}=$ Tamandaré $\mathrm{C}=$ Salvador city, $\mathrm{D}=$ Caravelas city, $\mathrm{E}=$ Abrolhos, $\mathrm{F}=$ Vitória city and $\mathrm{G}=$ Santa Cruz.

Figura 1. Mapa das localidades de coletas e cidades mais próximas. $\mathrm{A}=$ Cidade do Recife, $\mathrm{B}=$ Tamandaré, $\mathrm{C}=$ Cidade de Salvador, $\mathrm{D}=$ Cidade de Caravelas, $\mathrm{E}=$ Abrolhos, $\mathrm{F}=$ Cidade de Vitória e $\mathrm{G}=$ Santa Cruz.

City (northeastern Brazil). The Formoso and Mamucaba Rivers empty into the Atlantic Ocean, adding terrigenous sediments to the fringing reefs. The mean annual seawater temperature from 1988 to 1989 was $27.7^{\circ} \mathrm{C}$ and the mean annual salinity was $36.6 \%$ (Amaral 1991).

Abrolhos area (Figure 1), as described by Leão (1982), is located $65 \mathrm{~km}$ off the Brazilian coast and includes a group of coral reefs, volcanic islands, sand shoals, and surrounding channels that occupy an area of approximately $6000 \mathrm{~km}^{2}$ across the northern part of the Abrolhos Bank, between $17^{\circ} 20^{\prime}-18^{\circ} 10^{\prime} \mathrm{S}$ and $038^{\circ} 35^{\prime}-039^{\circ} 29^{\prime} \mathrm{W}$ (northeastern Brazil). Favia gravida colonies were collected at a fringing reef of Santa Bárbara Island. The mean annual seawater temperature from 1988 to 1989 was $27.1{ }^{\circ} \mathrm{C}$ and the mean annual salinity was 37\%o (Amaral 1991).

The Santa Cruz “iron sandstones" $19^{\circ} 49^{\prime} \mathrm{S}$ and $040^{\circ} 16^{\prime} \mathrm{W}$ (Figure 1) are situated about $56 \mathrm{~km}$ from Vitória City (southeast Brazil). The Doce River carries sediment to the beach. The mean annual seawater temperature from 1988 to 1989 was $21.8^{\circ} \mathrm{C}$ and the mean annual salinity was 36.6\% (Amaral 1991).

\section{Species studied}

Favia gravida (Verrill, 1868) is a poorly known Brazilian endemic species belonging to the suborder Faviina, superfamily Faviicae, family Faviidae, Favia Oken, 1815 (Laborel 1970). Some synonomies of Favia gravida are Favia conferta Verrill, 1868 and Meandra conferta Verrill, 1902.

In Brazil, Faviidae is represented by four species: Cladocora debilis Edwards and Haime, 1849 (an azooxanthellate species), Favia gravida, Favia leptophylla Verrill, 1868, and Montastraea cavernosa (Linnaeus, 1767). Favia gravida has a solid and dense colony with encrusting or hemispherical growth form, strong epitheca beneath, evenly rounded above, with equal, rounded, oval, and often deformed, deep cells, which are somewhat prominent above the general surface, and separated at equal distances, leaving concave, strongly costate interstices between them (Verrill 1868 apud Matthai 1919). 


\section{Sampling design}

Thirty colonies of Favia gravida between 10 and $20 \mathrm{~cm}$ large (sizes commonly found in the studied sites in depths less than $5 \mathrm{~m}$ ), were collected in the years of 1988 and 1989. Ten at each of the following three localities: Tamandaré (state of Pernambuco), Abrolhos (state of Bahia), and Santa Cruz (state of Espírito Santo). Uninjured colonies (e.g. normal pigmentation, continuous tissue cover, no lesions, etc.) were selected upon encounter (if of the desired size) for analysis and collected by free and SCUBA diving, with the aid of chisels and hammers. Both Tamandaré beach (PE) and Abrolhos National Marine Park (BA) are federally protected areas and collecting is tightly regulated. Therefore, it was not possible to collect more samples. The colonies were prepared by bleaching with 1:3 sodium hypochlorite solution, and air dried. The material is deposited in the Cnidaria Collection of the Museu Nacional/ Universidade Federal do Rio de Janeiro.

\section{Measurements and statistical methods}

For this study, the term "population" follows Foster (1978) and refers to colonies collected in one locality. Morphologic terms for the Scleractinia were also adapted from Foster (1978). Measurements were made on ten corallites per colony following the methods of Foster (1978), with at least three corallites on the colony top, middle, and side were selected randomly to be measured.

The corallites were measured at the University of Iowa by a "Summagraphics Digitizing Tablet" where it was possible to study fourteen measurements or counts in the samples from Tamandaré and Abrolhos: corallite length - CL, first cycle costae length - CSL, first cycle septa length - SSL, fourth cycle length - SFL, meander length - LM, centers per $9 \mathrm{~cm}^{2}$ number - NS1, corallites per meander number - NS2, first cycle septa per $3 \mathrm{~mm}$ number - NS3, septa per cm number - NS4, first cycle costae thickness - CST, first cycle septa thickness - SST, corallite width - CLW, columella width - CRW, and meander width - MW. Later (at the Museu Nacional do Rio de Janeiro), it was only possible to measure five characteristics using a vernier caliper, as the "Summagraphics Digitizing Tablet" was not available; the Santa Cruz samples were also studied in addition to the collection localities cited above.

These included the most important features used to distinguish species in the Faviidae: meander length, meander width, number of corallites per meander (meandrinization value), number of centers per $9 \mathrm{~cm}^{2}$, and number of septa per $\mathrm{cm}$.

Univariate analysis of variance (ANOVA) and canonical discriminant analysis (Gomes 1976, Dunn \& Everitt 1982, Sokal \& Rohlf 1983) were performed on colony means for the measured data. A significance level of $\mathrm{p}<0.05$ was used.

\section{Results}

Within each population, relevant differences were present for three critical morphological features: septa per cm number (NS4), corallites per meander number (NS2) and centers per $9 \mathrm{~cm}^{2}$ number (NS1). The meandrinization value (= the mean corallites per meander number) is 1.75 with the maximum value reaching 7 . The corallite length (CL) and the meander width (MW) did not present relevant variation (Table 1).

The majority of skeletal features varied statistically between Tamandaré and Abrolhos populations. ANOVA test showed that among 14 studied characters seven presented significant variation (Table 2).

Two skeletal characters varied statistically between Tamandaré, Abrolhos and Santa Cruz populations. ANOVA test showed that the septa per $\mathrm{cm}$ number (NS4) and centers per $9 \mathrm{~cm}^{2}$ number (NS1) were the most variable characters (Table 3), and Abrolhos colonies had the smallest values compared to other populations.

The values for the septa per $\mathrm{cm}$ of the Tamandaré ecomorphs (Figure 2) varied significantly in comparison to the other populations studied and the number of centers per $9 \mathrm{~cm}^{2}$ was different only in relation to the Abrolhos ecomorphs.
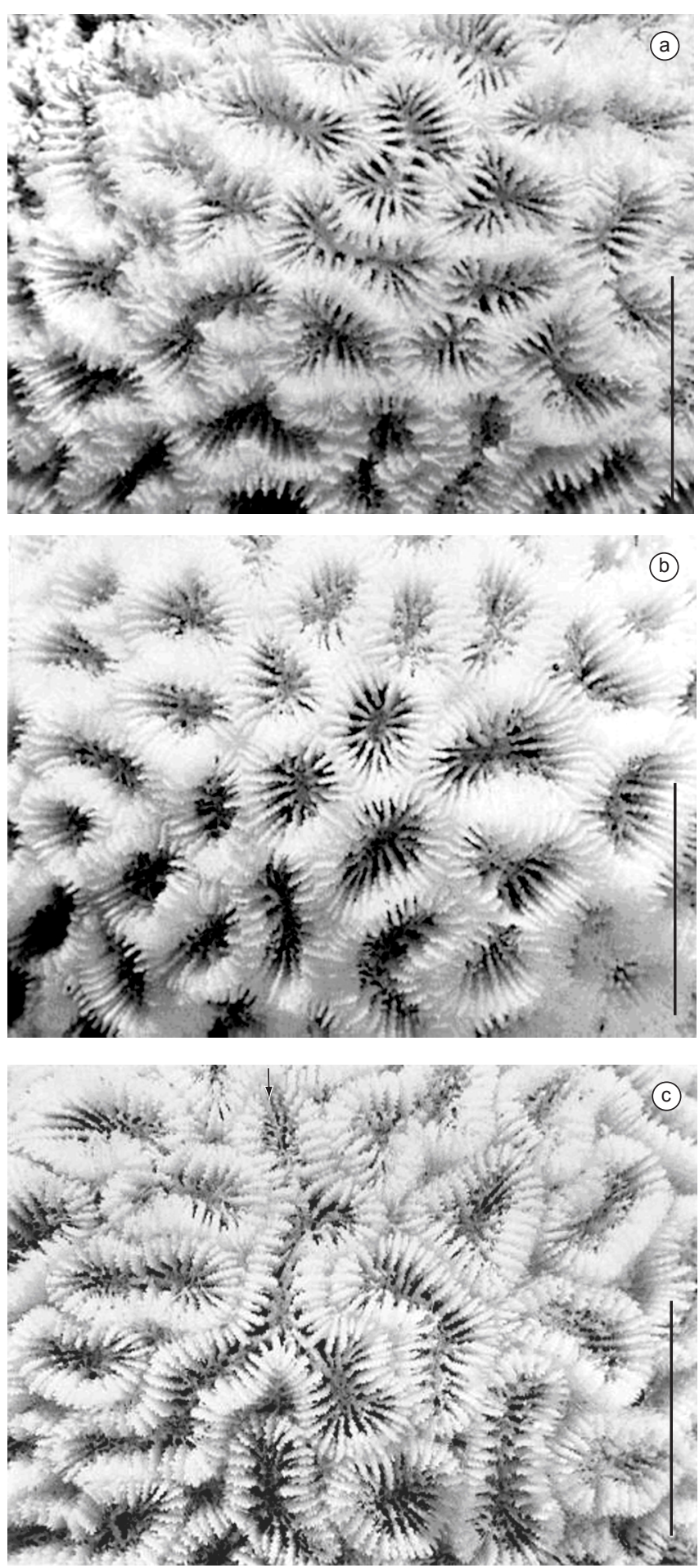

Figure 2. Photograph of Favia gravida from: a) Tamandaré, b) Abrolhos, and c) Santa Cruz. Scale $=2.00 \mathrm{~cm}$.

Figura 2. Fotografia de Favia gravida de: a) Tamandaré, b) Abrolhos, e c) Santa Cruz. Escala $=2,00 \mathrm{~cm}$. 
Table 1. Morphometry of Favia gravida LM = meander length, NS1 = centers per $9 \mathrm{~cm}^{2}$ number, NS2 = corallites per meander number, NS4 = septa per cm number, MW = meander width. Material measured with vernier caliper.

Tabela 1. Morfometria de Favia gravida. LM = comprimento do meandro, NS1 = número de centros por $9 \mathrm{~cm}^{2}$, NS2 $=$ número de coralitos por meandro, NS4 = número de septos por cm, MW = largura do meandro. Material medido com paquímetro.

\begin{tabular}{|c|c|c|c|c|c|c|}
\hline & Character & Mean* (mm) & SD & $\operatorname{Min}(\mathrm{mm})$ & $\operatorname{Max}(\mathrm{mm})$ & V.C. \\
\hline \multirow[t]{5}{*}{ Tamandaré } & LM & 8.87 & 1.33 & 6.26 & 11.08 & 14.98 \\
\hline & NS1 & 36.00 & 10.21 & 16.00 & 52.00 & 28.36 \\
\hline & NS2 & 1.85 & 0.29 & 1.50 & 2.30 & 15.76 \\
\hline & NS4 & 32.15 & 3.28 & 26.30 & 36.20 & 10.19 \\
\hline & MW & 4.19 & 0.45 & 3.73 & 5.18 & 10.66 \\
\hline \multirow[t]{5}{*}{ Abrolhos } & LM & 8.73 & 2.24 & 6.07 & 12.66 & 25.70 \\
\hline & NS1 & 31.00 & 9.49 & 22.00 & 50.00 & 30.60 \\
\hline & $\mathrm{NS} 2$ & 1.71 & 0.40 & 1.30 & 2.20 & 23.47 \\
\hline & NS4 & 19.48 & 6.09 & 13.40 & 28.20 & 31.25 \\
\hline & MW & 4.09 & 0.46 & 3.23 & 4.69 & 11.21 \\
\hline \multirow[t]{5}{*}{ Santa Cruz } & LM & 9.37 & 2.22 & 7.43 & 13.55 & 23.71 \\
\hline & NS1 & 44.30 & 8.76 & 33.00 & 62.00 & 19.77 \\
\hline & NS2 & 2.05 & 0.46 & 1.50 & 2.90 & 22.56 \\
\hline & NS4 & 28.66 & 2.25 & 25.10 & 31.30 & 7.86 \\
\hline & MW & 3.98 & 0.44 & 3.38 & 4.89 & 11.02 \\
\hline
\end{tabular}

*Mean of 10 colonies, SD = standard deviation, Min = colony minimal value, Max = colony maximum value, V.C.= variation coefficient

Table 2. Results of analysis of variance (ANOVA) between Tamandaré and Abrolhos populations of the studied characters of Favia gravida. CL $=$ corallite length, CSL = first cycle costae length, SSL = first cycle septa length, $\mathrm{SFL}=$ fourth cycle septa length, LM = meander length, NS1 = centers per $9 \mathrm{~cm}^{2}$ number, NS2 = corallites per meander number, NS3 = first cycle septa per $3 \mathrm{~mm}$ number, CST = first cycle costae thickness, SST = first cycle septa thickness, NS4 = septa per $\mathrm{cm}$ number, CLW = corallite width, CRW = columella width, MW = meander width. Material measured with "Summagraphics digitizing tablet".

Tabela 2. Resultados da Análise de Variância (ANOVA) entre os caracteres estudados das populações de Favia gravida de Tamandaré e Abrolhos. $\mathrm{CL}=$ comprimento do coralito, $\mathrm{CSL}=$ comprimento das costelas do primeiro ciclo, SSL = comprimento dos septos do primeiro ciclo, $\mathrm{SFL}=$ comprimento dos septos do quarto ciclo, $\mathrm{LM}=$ comprimento do meandro, NS1 = número de centros por $9 \mathrm{~cm}^{2}, \mathrm{NS} 2$ = número de coralitos por meandro, $\mathrm{NS} 3=$ número de septos do primeiro ciclo em $3 \mathrm{~mm}, \mathrm{CST}=$ espessura das costelas do primeiro ciclo, $\mathrm{SST}=$ espessura dos septos do primeiro ciclo, NS4 = número de septos por $\mathrm{cm}, \mathrm{CLW}=$ largura do coralito, $\mathrm{CRW}=$ largura da columela, $\mathrm{MW}=$ largura do meandro. Material medido com mesa digitalizadora.

\begin{tabular}{crc}
\hline Character & $\mathbf{F}_{\mathbf{1 , 1 8}}$ & $\mathbf{P}$ \\
\hline CL & 2.08 & 0.1798 \\
CSL & 0.99 & 0.3436 \\
SSL & 2.89 & 0.1201 \\
SFL & 2.74 & 0.1290 \\
LM & 5.24 & $0.0001 *$ \\
NS1 & 5.00 & $0.0142 *$ \\
NS2 & 2.63 & 0.0039 \\
NS3 & 1.60 & 0.2343 \\
CST & 2.76 & 0.1278 \\
SST & 31.78 & $0.0002 *$ \\
NS4 & 148.11 & $0.0001 *$ \\
CLW & 7.70 & $0.0196 *$ \\
CRW & 12.20 & $0.0058^{*}$ \\
MW & 3.31 & $0.0004 *$ \\
\hline
\end{tabular}

* Statistically significant $(\mathrm{p}<0.05)$
Table 3. Results of analysis of variance (ANOVA) between Tamandaré (T), Abrolhos (A) and Santa Cruz (SC) populations of the studied characters of Favia gravida. LM = meander length, NS1 = centers per $9 \mathrm{~cm}^{2}$ number, NS2 = corallites per meander number, NS4 = septa per $\mathrm{cm}$ number, $\mathrm{MW}=$ meander width. Material measured with vernier caliper.

Tabela 3. Resultados da Análise de Variância (ANOVA) entre os caracteres estudados das populações de Favia gravida de Tamandaré (T), Abrolhos (A) e Santa Cruz (SC). LM = comprimento do meandro, NS1 = número de centros por $9 \mathrm{~cm}^{2}, \mathrm{NS} 2$ = número de coralitos por meandro, NS4 = número de septos por $\mathrm{cm}, \mathrm{MW}=$ largura do meandro. Material medido com paquímetro.

\begin{tabular}{crlc}
\hline Character & $\mathbf{F}_{2,27}$ & \multicolumn{1}{c}{$\mathbf{p}$} & a posteriori comparison \\
\hline LM & 0.29 & 0.7521 & \\
NS1 & 5.00 & $0.0142^{*}$ & $\mathrm{~A}<\mathrm{T}=\mathrm{SC}$ \\
NS2 & 1.90 & 0.1683 & \\
NS4 & 24.30 & $0.0001 *$ & $\mathrm{~A}<\mathrm{SC}<\mathrm{T}$ \\
MW & 0.51 & 0.6075 & \\
\hline
\end{tabular}

* Statistically significant $(\mathrm{p}<0.05)$

The results of canonical discriminant analysis $(R=0.8648)$ showed that the Abrolhos colonies were most distinct from those of Tamandaré and Santa Cruz, which in turn contain a small overlaping area (Figure 3). The first canonical variate accounted for $85.97 \%$ of the variation and the second canonical variate for $14.03 \%$ (Table 4 ). The most heavily weighted characters to the first canonical variate were the number of septa per $\mathrm{cm}$, the number of centers per $9 \mathrm{~cm}^{2}$, and the number of corallites per meander.

\section{Discussion}

All specimens in this study were collected in water ranging from 1 to $5 \mathrm{~m}$ deep in low tide. Therefore, the colonies from all three localities can be expected to display an intermediate form close to that described by Laborel (1970). However, the water at Abrolhos is 


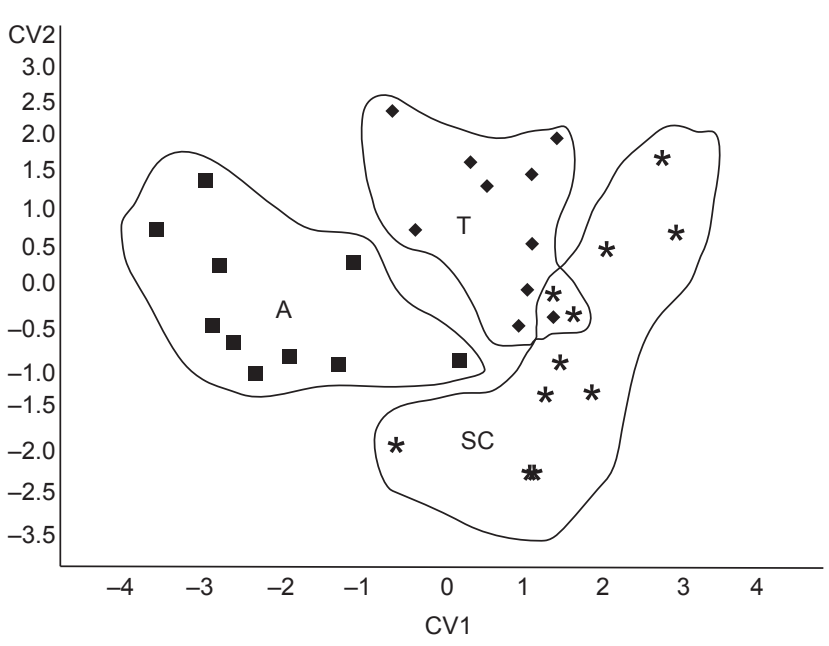

Figure 3. Results of the canonical discriminant analysis of Favia gravida. Canonical variate 2 versus canonical variate $1 . \mathrm{N}=10$ for each population. ( $\mathrm{T}=$ Tamandaré, $\mathrm{A}=$ Abrolhos, $\mathrm{SC}=$ Santa Cruz).

Figura 3. Resultados da Análise Canônica Discriminante de Favia gravida. Variável Canônica 2 versus Variável Canônica $1 . \mathrm{N}=10$ para cada população. ( $\mathrm{T}=$ Tamandaré, $\mathrm{A}=$ Abrolhos, $\mathrm{SC}=$ Santa Cruz)

Table 4. Results of the canonical discriminant analysis of Favia gravida from Tamandaré, Abrolhos and Santa Cruz in the two canonical axes. N = 10 for each population. $\mathrm{CV}=$ canonical variate, $\mathrm{LM}=$ meander length, $\mathrm{NS} 1=$ centers per $9 \mathrm{~cm}^{2}$ number, NS2 $=$ corallites per meander number, NS4 $=$ septa per $\mathrm{cm}$ number, MW = meander width. Material measured with vernier caliper.

Tabela 4. Resultados da Análise Canônica Discriminante de Favia gravida de Tamandaré, Abrolhos e Santa Cruz em dois eixos canônicos. $\mathrm{N}=10$ para cada população. $\mathrm{CV}$ = variável canônica, $\mathrm{LM}=$ comprimento do meandro, NS1 = número de centros por $9 \mathrm{~cm}^{2}$, NS2 = número de coralitos por meandro, NS4 = número de septos por $\mathrm{cm}, \mathrm{MW}=$ largura do meandro. Material medido com paquímetro.

\begin{tabular}{lll}
\hline \multicolumn{1}{c}{ Character } & CV1 & CV2 \\
\hline LM & 0.0808 & 0.2214 \\
NS1 & $0.3753^{*}$ & $0.7106^{*}$ \\
NS2 & 0.2666 & $0.4647^{*}$ \\
NS4 & $0.9264^{*}$ & -0.0553 \\
MW & 0.0441 & -0.3265 \\
Correlation & 0.8649 & 0.5713 \\
Eigenvalue & 2.9682 & 0.4845 \\
Proportion & 0.8597 & 0.1403 \\
Accumulative & 0.8597 & 1.0000 \\
\hline
\end{tabular}

* The most heavily weighted characters

calmer than at Tamandaré and Santa Cruz and this may be reflected by the less pronounced meandrinization seen in these samples.

Ecomorphs of some Faviidae have previously been described qualitatively (Wijsman-Best 1974, Best et al. 1983), but the results of this canonical discriminant analysis show quantitatively that the range in variation that exists in the Brazilian populations of Favia gravida is considerable. In fact the variability in Favia gravida documented in this study extends Matthai's 1919 description (Amaral 1991). The same characters that vary within populations also vary among populations (e.g., septa per $\mathrm{cm}$ number and corallites per $9 \mathrm{~cm}^{2}$ number) which suggests that genetic variation and phenotypic plasticity are not easily recognized. According to Foster (1978), plasticity is an important attribute and can be considered a mechanism that controls the abundance of corals in the reefs. The present study reinforces the idea of the absence of stable morphological patterns in corals and the importance of genetic variation (Knowlton et al. 1992, Veron 1995, 2000, Santos 2003).

Favia gravida displays high morphological plasticity, which might contribute to its ability to occupy a great range of habitats in the Brazilian coast. For example: in Pernambuco State, Santos et al. (2004a) cited lower meander length and width values for the colonies from Enseada dos Corais Beach; this is can probably be explained by the fact that this locality is more accessible for tourists than Tamandaré.

The results presented here agree with Laborel (1970): Favia gravida showed variations in meander form, development of the exotheca and number of septa, but his work did not involve statistical analysis. His meandrinization values ranged from 1 to 4 (Laborel 1970); however, in this study the values were as high as 7 in colonies from Santa Cruz. Laborel (1970) associated this characteristic with disturbances provoking variations in environmental parameters. Additionally, Barnes (1973) hypothesized that the meandroid form of the corallites was associated with increased biomass and insufficient calcification.

Johnson (1988), studying the effects of the micro- and macrogeographical variations in relation to colony size and meander complexity of Manicina areolata (Linnaeus), suggested that the meander pattern is an adaptive character and is subject to significant local variation. He also suggested that the meander complexity increases in response to environmental stimuli and is probably related to the coral's capacity to tolerate sediment loading. This study of Favia gravida confirms these expectations: that is, the specimens from Santa Cruz, a turbid area, were highly meandrinized. In addition, seawater temperature is 5 degrees lower than at the Abrolhos and Tamandaré beaches. The mean annual seawater temperature from 1988 to 1989 was $27.1^{\circ} \mathrm{C}$ in Abrolhos, $27.7^{\circ} \mathrm{C}$ in Tamandaré, and $21.8^{\circ} \mathrm{C}$ in Santa Cruz (Amaral 1991). Different from Santos (2003) that found patterns uniting the populations of Favia gravida from northeastern Brazil and separating them from the populations of the southeast, we observed the separation of the population from Bahia (BA) and the overlap of the populations from Tamandaré (PE) and Santa Cruz (ES).

\section{Conclusions}

The results of this study show that the same characters that vary among populations (e.g., number of septa per $\mathrm{cm}$ and number of corallites per $9 \mathrm{~cm}^{2}$ ) also vary within populations, which reinforces the idea that there are no stable morphological patterns for Brazilian Favia gravida.

The geographical distance separating Abrolhos' Favia gravida colonies from the mainland of was probably the principal cause of the differences observed between the colonies there. The similarities observed among the coastal populations were probably related to the influence of fresh water and terrigenous sediments carried from the coast.

\section{Acknowledgments}

We would like to thank to the kind Julie Golden and Dr. Ann F. Budd of University of Iowa, Dr. Maria Júlia da C. Belém, Dr. Clóvis B. Castro and Paulo S. Young of the Museu Nacional (UFRJ), for their suggestions in the earlier version of the manuscript. We are grateful to Andrea Steiner and Michelle Santos for their help and to Dr. Douglas Fenner of Australian Institute of Marine Science for his important comments. Thanks to the CNPq for the first author's 
research fellowship. Also many thanks to anonymous reviewers for improving the first draft of the manuscript.

\section{References}

AMARAL, F.D. 1991. Variação morfológica dos esqueletos de Montastraea cavernosa (Linnaeus, 1767) e Favia gravida Verrill, 1868 (Cnidaria, Scleractinia). Dissertação de Mestrado. Universidade Federal do Rio de Janeiro, Rio de Janeiro.

AMARAL, F.D. 1994. Morphological variation in the reef coral Montastrea cavernosa (Linnaeus, 1767) in Brazil. Coral Reefs 13(2):113-117.

AMARAL, F.D., SILVEIRA, S.R.M., VASCONCELOS, S.L. \& RAMOS, C. A. C. 2006. Biodiversidade de cnidários bentônicos. In: VASKE JÚNIOR, T., LESSA, R.P., NÓBREGA, M.F., AMARAL, F.M.D. \& SILVEIRA, S.R.M. 2006. Arquipélago de São Pedro e São Paulo: histórico e recursos naturais. Olinda, Ed. Livrorápido. p. 42-55.

ANTÔNIO-DE-SOUZA, C. \& AMARAL, F.D. 2001. Variação morfológica de algumas espécies de corais Mussidae (Cnidaria, Anthozoa) do Brasil. Tropic. Oceanogr. 29(2):81-95.

BARNES, D.J. 1973. Growth in colonial scleractinians. Bull. Mar. Sci. 23(2):280-298.

BATTEY, J.F. \& PORTER, J.W. 1988. Photoadaptation as a whole organism response in Montastraea annularis. In Int. Coral Reef Symp. 6. Proceedings 3:79-87.

BELTRÁN-TORRES, A.U. \& CARRICART-GANIVET, J.P. 1993. Skeletal morphologic variation in Montastrea cavernosa (Cnidaria: Scleractinia) at Isla Verde Coral Reef, Veracruz, Mexico. Rev. Biol. Trop. 41(3):559-562.

BEST, M.B., BOEKSCHOTEN, G.J. \& OOSTERBAAN, A. 1983. Species concept and ecomorph variation in living and fossil Scleractinia. Palaeontogr. Am. 54:70-79.

BRAKEL, W.H. 1977. Corallite variation in Porites and the species problem in corals. Int Coral Reef Symp, 3. Proceedings 1:457-462.

BROOK, G. 1893. The genus Madrepora. v.1. p. 1-59. In: Catalogue of the madreporarian corals in the British Museum Natural History. London.

BUDD, A.F. 1988. Large-scale evolutionary patterns in the reef-coral Montastraea: The role of phenotypic plasticity. In Int. Coral Reef Symp. 6. Proceedings 3:393-398.

CARLON, D.B. \& BUDD, A.F. 2002. Incipient speciation across a depth gradient in a scleractinian coral? Evolution 56:2227-2242.

CHEN, C.A., WALLACE, C.C. \& WOLSTENHOLME, J. 2002. Analysis of the mitochondrial 12S rRNA gene supports a two-clade hypothesis of the evolutionary history of scleractinian corals. Mol. Phylogen. Evol. 23:137-149.

CRUZ-PIÑÓN, G., CARRICART-GANIVET, J.P. \& ESPINOZA-AVALOS, J. 2003. Monthly skeletal extension rates of the hermatypic corals Montastraea annularis and Montastraea faveolata: biological and environmental controls. Mar. Biol. 143(3):491-500.

DUNN, G. \& EVERITT, B.S. 1982. An introduction to mathematical taxonomy. Cambridge University Press. Cambridge. 154p.

DUSTAN, P. 1975. Growth and form in the reef-building coral Montastrea annularis. Mar. Biol. 33:101-107.

FOSTER, A.B. 1978. Morphologic variation within three species of reef corals (Cnidaria, Anthozoa, Scleractinia) Baltimore, PhD. thesis. Johns Hopkins University. 468p.

FOSTER, A.B. 1983. The relationship between corallite morphology and colony shape in some massive reef-corals. Coral Reefs 2:19-25.

FRICKE, H.W. \& SCHUHMACHER, H. 1983. The depth limits of Red Sea stony corals: an ecophysiological problem (a deep diving survey by submersible). Mar. Ecol. 4(2):163-194.

GOMES, F. P. 1976. Curso de estatística experimental. Ed. Nobel. 430p.

GRAUS, R.R. \& MACINTYRE, I.G. 1982. Variation in growth forms of the reef coral Montastrea annularis (Ellis and Solander): a quantitative evaluation of growth response to light distribution using computer simulation. The Atlantic Barrier Reef ecosystem at the Carrie Bow Cay, BelizeSmithson Contr. Mar. Sci. 12:441-464.

HUGHES, T.P. 1987. Skeletal density and growth form of corals. Mar. Ecol. Prog. Ser. 35:259-266.

JOHNSON, K.G. 1988. Size, meander pattern, and behavior in the Caribbean free-living meandroid coral Manicina areolata (Linnaeus). In Int. Coral Reef Symp. 6. Proceedings 3:403-408.

KNOWLTON, N.; WEIL, E.; WEIGTH, L.A. \& GUZMÁN, H.M. 1992. Sibling species in Montastrea annularis, coral bleaching and coral climate record. Science 255:330-333.

KRUSZYNSKI, K.J.; van LIERE, R. \& KAANDORP, J.A. 2006. An interactive visualization system for quantifying coral structures. Eurographics Association, 8p.

LABOREL, J. 1970. Madréporaires et hydrocoralliaires récifaux des cotes brésiliennes. Ann. Inst. Océanogr. 47(25):171-229.

LANG, J.C. 1984. Whatever works: the variable importance of skeletal and nonskeletal characters in scleractinian taxonomy. Palaeontogr. Am. 54:18-44.

LASKER, H.R. 1979. Light dependent activity patterns among reef corals Montastrea cavernosa. Biol. Bull. 156:196-211.

LASKER, H.R. 1981. Phenotypic variation in the coral Montastrea cavernosa and its effects on colony energetics. Biol. Bull. 160:292-302.

LEÃO, Z.M.A.N. 1982. Morphology, geology and developmental history of the southermost corals reefs of Western Atlantic, Abrolhos Bank, Brazil. $\mathrm{PhD}$ Dissertation. University of Miami. 218p.

MATTHAI, G. 1919. On Favia conferta, Verrill, with notes on the other Atlantic species of Favia. Nat Hist Rep Br Antarct Terra Nova Exped 1910 5(2):69-96.

MAYAL, E. \& AMARAL, F.D. 1990. Ecomorfose em alguns escleractínios da costa pernambucana. Trab. oceanog. 21:239-251.

MERKS, R.M.H., HOEKSTRA, A.G., KAANDORP, J.A. \& SLOOT, P.M.A. 2004. Polyp oriented modelling of coral growth. J. Theor. Biol. 228:559-576.

MORRI, C., PEIRANO, A. \& NIKE BIANCHI, C. 2001. Is the Mediterranean coral Cladocora caespitosa an indicator of climatic change? Arch. Oceanogr. Limnol. 22:139-144.

PALUMBI, S.R. 1994. Genetic divergence, reproductive isolation, and marine speciation. Ann. Rev. Ecol. Syst. 25:547-572.

SANTOS, M.G. 2003. Comparação morfológica de Favia gravida e Siderastrea stellata (Cnidaria: Scleractinia) do Brasil com espécies congêneres do Caribe panamenho. Dissertação (Mestrado em Zoologia). Universidade Federal da Paraíba. Paraíba. 97p.

SANTOS, M.G., AMARAL, F.D., HERNÁNDEZ, M.I.M., KNOWLTON, N. \& JARA, J. 2004a. Variação morfológica de Favia gravida Verrill, 1868 e Siderastrea stellata Verrill, 1868: aspectos esqueléticos. Bolm Mus. Nac., Zool. 517:1-9.

SANTOS, M.G., AMARAL, F.D., SÁ, F.B. \& LIMA, M.G.A. 2004b. Morphological plasticity of Montastrea cavernosa and Siderastrea stellata (Cnidaria: Scleractinia) from Maranhão, Paraíba and Pernambuco States, Brazil. Biol. Gen. Exp. 5(1):5-11.

SOKAL, R.R. \& ROHLF, F.J. 1983. Biometry. The principles and practice of statistics in biological research. $2^{\text {nd }}$ ed., 859p. WH Freeman. New York.

STANLEY Jr., G.D. 2003. The evolution of moderns corals and their early history. Earth Sci. Rev. 60:195-225.

TODD, P.A., LADLE, R.J., LEWIN-KOH, N.J.I. \& CHOU, L.M. 2004a. Flesh or bone? Quantifying small-scale coral morphology using with-tissue and without-tissue techniques. Mar. Biol. 145(2):323-328.

TODD, P.A., SIDLE, R.C. \& LEWIN-KOH, N.J.I. 2004b. An aquarium experiment for identifying the physical factors inducing morphological change in two massive scleractinian corals. J. Exp. Mar. Biol. Ecol. 299:97-113.

TODD, P.A., SANDERSON, P.G. \& CHOU, L.M. 2001. Morphological variation in the polyps of the scleractinian coral Favia speciosa (Dana) around Singapore. Hydrobiologia 444(1-3):227-235. 
VAUGHAN, T.W. \& WELLS, J.W. 1943. Revision of the suborders, families and genera of Scleractinia. Spec. Pap. Geol. Soc. Am. 44:1-363.

VERON, J.E.N. 1981. The species concept in "Scleractinia of Eastern Australia". Int Coral Reef Symp, 4. Proceedings 2:183-186.

VERON, J.E.N. 1995. Corals in space and time. Comstrock/ Cornell Ithaca, New York, 321p.

VERON, J.E.N. 2000. Corals of the world. Australian Institute of Marine Science (AIMS), Queensland, Australia, vols. 1-3, 1410p.
WILLIS, B.L. 1985. Phenotypic plasticity versus phenotypic stability in the reef corals Turbinaria mesenterina and Pavona cactus. In Int. Coral Reef Symp. 5. Proceedings 4:107-112.

WIJSMAN-BEST, M. 1974. Habitat-induced modification of reef corals (Faviidae) and its consequences for taxonomy. In Int. Coral Reef Symp. 2. Proceedings 2:217-228. 
